\title{
IN SILICO DESIGN OF Butea monosperma FLORAL DERIVED COMPOUNDS AND ITS INHIBITORY EFFECT ON $\beta$-CATENIN, GSK-3 $\beta$ AND APC COMPLEX PROTEINS IN COLORECTAL CANCER
}

\author{
NAVANEETHAKRISHNAN P. ${ }^{1}$, PRASHANTHA C.N. ${ }^{2}$, BOOPATHI S. ${ }^{1}$, SABITHA R. ${ }^{1}$ AND MATHAN G. ${ }^{1 *}$ \\ 1Department of Biomedical Science, Bharathidasan University, Tiruchirappalli- 620024 , TN, India. \\ 2Bioinformatics Group, Scientific Bio-Minds, Bangalore- 560 092, Karnataka, India. \\ ${ }^{*}$ Corresponding Author: Email- mathan@bdu.ac.in
}

Received: November 04, 2013; Accepted: November 21, 2013

\begin{abstract}
Wnt/ $\beta$-Catenin signaling pathway plays a major role in embryonic development and tumorogenesis on several human cancers. In

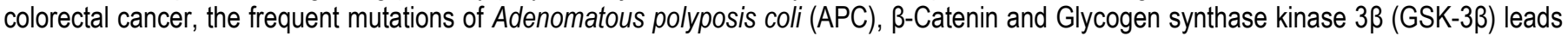
to accumulate the unphosphorylated $\beta$-catenin in cytoplasm. Further, its translocate into the nucleus, where it interacted with T-cell factor/ Lymphocyte enhancer factor (TCF/LEF) family of transcription factors to activate inappropriate expression of downstream targets. Therefore, Wnt/ $\beta$-Catenin signaling proteins are mainly focused as potential therapeutic targets on colorectal cancer. In recent investigations, the antitumorogenic and chemopreventive property of phytochemicals extracted from the flowers of Butea monosperma $(B m)$ has been elucidated by using transgenic and rodent animal models. In the present study, the eight major compounds of $n$-butanol fractions of $B m$ flowers were docked against Wnt/B-Catenin signaling proteins by using AutoDock tool v 4.2 and ADT v1.5.4. The incurred active compounds of butrin and isobutrin showed a good binding interaction with Wnt/ $\beta$-Catenin proteins. Hence, this finding suggesting that butrin and isobutrin would be considered as a potent antitumorogenic drug to target Wnt/ $\beta$-Catenin associated cancers.
\end{abstract}

Keywords- Wnt/ $\beta$-catenin, docking, colorectal cancer, Butea monosperma, Butrin, Isobutrin

Citation: Navaneethakrishnan P., et al. (2013) In Silico Design of Butea monosperma Floral Derived Compounds and Its Inhibitory Effect on $\beta$ Catenin, GSK-3ß and APC Complex Proteins in Colorectal Cancer. International Journal of Drug Discovery, ISSN: 0975-4423 \& E-ISSN: 0975914X, Volume 5, Issue 1, pp.-191-197.

Copyright: Copyright@2013 Navaneethakrishnan P., et al. This is an open-access article distributed under the terms of the Creative Commons Attribution License, which permits unrestricted use, distribution and reproduction in any medium, provided the original author and source are credited.

\section{Introduction}

Dysregulation of Wnt signaling pathway often plays a crucial role in many human tumorogenesis, especially in the development of colorectal cancer (CRC) [1]. The mutations of $\beta$-catenin, Adenomatous polyposis coli (APC) and glycogen synthase kinase $3 \beta$ (GSK-3ß) in $\mathrm{CRC}$ eventually exist as a key to delineate the activation of canonical Wnt pathway in majority of tumors [2].

Wnt/ $\beta$-catenin signaling has diverse functions in cellular processes such as proliferation, differentiation, migration and the survival of cells. In certain, the non-canonical Wnt signaling protein controls the tissue polarity and its movement. While in the absence of Wnt, the Cytosolic $\beta$-catenin protein has degraded by destruction complex, which composed of Axin, APC and GSK-3 $\beta$ through Ubiquitin mediated 26s proteasome degradation pathway. However, the Wnt ligand binds to its Frizzled (Fz) receptor and its co receptor of low density lipoprotein receptor -related protein 5/6 (LRP5/6) that forms a complex with an intracellular Disheveled (Dv1) protein. Yet, this complex phosphorylated and suppressed the GSK-3 $\beta$ from the phosphorylation event of $\beta$-catenin. The stabilized unphosphorylated $\beta$-catenin which accumulated in the cytoplasm fur- ther translocate into the nucleus where it interacts with the T-cell factor/Lymphocyte enhancer factor (TCF/LEF) family of transcription factors that activates the expression of downstream target genes such as $c-M y c, c-J u n$, fra1, urokinase-type plasminogen activator receptor (UPAR), matrysin, Cyclin D1,PPARס and WISP [3 -9].

A serine/threonine protein kinase, GSK3 $\beta$ has regulated number of signaling pathways and various biological processes [10]. The GSK $-3 \beta$ is the super family of mitogen-activated protein (MAP) kinases which encodes two genes of GSK-3 $\alpha$ and GSK-3 $\beta$ that involved in various diseases like inflammation, Type II diabetes and cancer [11]. In Wnt signaling, the phosphorylated GSK-3 $\beta$ usually subdued the activity of its downstream targets by phosphorylating the $\beta$ catenin [12]. The 420 amino acids (AA) length of GSK-3 $\beta$ carries 56 to 347 amino acids of phosphokinase, ATP binding sites, substrate binding sites and also it might be a "tumor promoter" for certain types of Wnt pathway. For this cause, the inhibition of GSK3 $\beta$ has been proposed to be an attractive therapeutic approach for the treatment of CRC [13].

The mutated tumor suppressor gene, APC was originally identified 
as a major causative genetic factor for developing numerous colorectal polyps towards familial adenomatous polyposis coli (FAP) affected patients. It possessed 2843 AA with various binding domains in its $\mathrm{N}$ and $\mathrm{C}$-terminal regions. With this, the $\mathrm{N}$-terminal region had oligomerization domain, 7 armadillo repeats followed by $15 \mathrm{AA}$ and $20 \mathrm{AA}$ repeats in two $\beta$-catenin binding sites, located at the residues of 1020-1169 and 1342-2075 AA respectively. Among these two binding sites, the 20 AA repeat had high affinity upon phosphorylation whereas the functional significance of $15 \mathrm{AA}$ residues is still obscure [14]. On the other hand, the C-terminal region holds basic domain, the binding site for end-binding protein-1 (EB1) and discs-large (DLG) protein [15].

The $781 \mathrm{AA}$ of $\beta$-catenin is the chief role in cell-cell adhesion by interacting with cadherin family proteins. This protein (NP_001091679.1) was homologous to Armadillo repeats (ARM) and its $x$-ray crystallographic structure, depicted that $\beta$-catenin has $435 \mathrm{AA}$ in alpha helix at three different positions. The $\mathrm{N}$-terminal region holded $130 \mathrm{AA}$, whereas in central region and $\mathrm{C}$-terminal region had $550 \mathrm{AA}$ and $100 \mathrm{AA}$ approximately. As well, it acquitted $37 \mathrm{AA}$ in extended strands, $34 \mathrm{AA}$ in beta turns and $275 \mathrm{AA}$ in random coils. Furthermore, the $\mathrm{N}$-terminal region had a consensus phosphorylation sites for GSK-3 $\beta$ and there was transactivator function required to activate the target genes, present in C-terminal region [16]. Whereas, the central region contained 12 imperfect sequence repeats of 42 amino acids known as armadillo repeats really requisite to interact with various proteins including cadherins, APC and TCF/LEF [17]. It was interesting to note that the central region of APC also eased the repeats of Ser-Ala-Met-Pro (SAMP) motif which bound to Axin or conductin, essential for optimal regulation in Wnt signaling pathway [18]. Most of the tumor-associated mutations in the APC gene have been mapped within the central region (residues 1286-1513) [19]. Thus APC mutations resulted in truncated proteins could have lack in all axin/conductin-binding motifs (SAMP) and in a few $\beta$-catenin-binding 20 AA repeats [20].Therefore, the identification of these regulatory proteins and its target sites offered an ample opportunity to develop a new therapy for CRC. Thus growing evidence supported that the bioactive compounds identified from natural sources would exert a potential anticancer activity and some of them were more specific to particular cellular targets.

In this series, Butea monosperma (Lam.) (Family Fabaceae) have been illustrated as a valuable medicinal plant with more than 45 medicinal attributes. And it has broad spectrum of activity ascend with diverse type of pathogens, cancer and several diseases [21, 22]. Concurrently, this extracts constitutes phytochemical compounds/ flavonoids such as butrin, isobutrin [23], butein, butin, coreopsin, isocoreopsin, monospermoside and isomonospermoside [24]. Amongst, Butrin/Isobutrin proposed to have a potential antitumorogenic property in transgenic mouse and rodent models [25]. Therefore, in the present study, focused to target the binding interaction of these major eight compounds against with the three mutated Wnt signaling proteins, $\beta$-catenin, APC and GSK-3 $\beta$, through in silico docking methods.

\section{Materials and Methods \\ Homology Modeling}

The target sequences of $\beta$-catenin, APC and GSK-3 $\beta$ domains of Wnt Signaling proteins were incurred from UniProtKB protein knowledgebase (IDs: P35222, P25054 and P49841 respectively) and persuaded by using PSI-BLAST from NCBI to identify the tem- plate sequences. Further, the three dimensional protein structures were built by using Swiss PDB Viewer (SPDBV) and the protein structure by Modeller 9.12 (http://salilab.org/modeller/about_model ler.html) [26-29]. The resultant 3D structure quietly underwent for quality analysis based on stereochemistry of residue by residue geometry and overall structural geometry using structure analysis and verification server (SAVS). Hence, this quality determination of modeled structure predicted WHATIF, ERRAT, PROCHECK [3033].

\section{Active Site Prediction}

Using modeled 3D protein structure, the possible binding sites were searched using Q-site finder [34] to predict the ligand binding site and also whole protein structure assumed as binding sites. The active site amino acids has kneaded by binding hydrophobic probes to the protein and found the clusters of probes with the most favorable binding energy [www.bioinformatics.leeds.ac.uk/qsitefinder]. The calculation of interaction energy between the protein and a simple Van-der-waals force has meant to locate energy depending binding sites. The energizing clustered templates with spatial proximity and clusters were rated according to the sum of interaction energies within each cluster. Plausibly, the ligand binding pockets of modeled 3D protein structures were computed, accordance on geometric accuracy of RMSD and superimposition of target with respect to its native structure [35].

\section{Ligand Preparation}

The characteristic of phytochemicals butrin, isobutrin, butein, butin, coreopsin, isocoreopsin (butin 7-glucoside), monospermoside (butein 3-e-D-glucoside) and Isomonospermoside compounds were retrieved from Pub chem Database (http://pubchem.ncbi.nlm.nih.go v/search/ search.cgi). The training sets of ligand molecules were generated through conformational search module and further implementation has been done by Hyperchem Professional 7.0.

\section{Molecular Docking}

Docking analysis of those 8 major ligands were docked with Wnt/Bcatenin signaling proteins by using AutoDockTools (ADT) v 1.5 .4 and AutoDock v 4.2 program; (Autodock, Autogrid, Autotors, Copyright-1991e2000) from the Scripps Research Institute, http:// www.scripps.edu/mb/olson/ doc/autodock. To run AutoDock, the autogrid was setted by creating grid maps of different grid points for keeping ligands to cover binding pockets, fully based on active site amino acids within the selected protein. Polar hydrogen was added to the ligand moieties along with Gasteiger-type were assigned and the nonpolar hydrogens were merged with the carbons and the internal degrees of freedom and torsions were set. A set of Lamarckian genetic algorithm was substantially used for molecular docking simulations. The parameters such as population size of 150 , the mutation rate of 0.02 and crossover rate of 0.8 were fixed accordingly. Secondly, the Simulations were performed up to 2.5 million energy and the evaluations were maximum at 27000 generations. Each simulation was carried about 10 times which ultimately yielded 10 docked conformations. From this, the lowest energy conformations were regarded as the best binding conformations. In the end, the reverse validation processes ensured the identified hits that fitted with generated pharmacophore models and active sites of both targets. Since all the parameters were required for molecular docking and Pharmacophore mapping were consequently fixed and used in regular process [36,37]. 


\section{Results and Discussion Homology Modeling}

The selected Wnt/ß-catenin protein sequences were aligned and modeled using PSI-BLAST program. The scores were enlisted as descending order where the proteins most likely to bind with ligand, would be clustered at the top. Also, the scores generated were based on sequence similarity between target and template peptides of $\beta$-catenin, APC and GSK-3 $\beta$ [Table-1]. As a result, the $\beta$-catenin contained 32 templates; amongst all; the $\beta$-catenin of zebrafish showed $97 \%$ sequence similarity in an alignment of 1-781 amino acids. The APC protein contained 11 templates, among them; the $\beta$ -catenin of 20 AA repeat fragments showed $94 \%$ similarity with phosphorylated APC complex. When in GSK-3 $\beta$, it was holded about $35 \%$ similarity to Apo CDK2 protein. Hence, the result of these uncharacterized templates sequences has shown significant similarity with target proteins and functional properties. Therefore, we designed these sequences as three dimensional homology models.

Table 1- Sequence similarities of Wnt/ $\beta$-catenin signaling proteins

\begin{tabular}{|c|c|c|c|}
\hline Target sequence & Template Id & $\%$ of Seq. Similarity & Seq. coverage \\
\hline P35222 & $2 z 6 g A$ & 97 & $1-781$ \\
\hline \multirow{3}{*}{$\beta$-catenin } & $2 z 6 h A$ & 100 & $138-781$ \\
\hline & $2 g \mid 7 A$ & 99 & 138-781 \\
\hline & 1jpwB & 99 & $131-670$ \\
\hline P25054 & $2 n m z A$ & 99 & $326-736$ \\
\hline \multirow{3}{*}{ APC } & $1 \mathrm{mbiA}$ & 95 & $130-239$ \\
\hline & 1th1C & 94 & $1468-1529$ \\
\hline & 1V18B & 91 & $1485-1528$ \\
\hline P49841 & 3PxrA & 35 & $55-346$ \\
\hline GSK-3及 & $3096 \mathrm{~A}$ & 31 & $4-340$ \\
\hline
\end{tabular}

The target and the template sequences (PDB ID: 2Z6G_A, 1TH1_C, 3PXR_A) were aligned by using Swiss Model, the comparative protein modeler. The theoretical models were subjected to the model used in Swiss-PDB-viewer. Here, the obtained protein structures were superimposed in order to deduce the structural alignment. After completion of modeling, the 3D structures of $\beta$ catenin [Fig-1](a), APC [Fig-1](b) and GSK-3 $\beta$ [Fig-1](c) were expressed $99 \%, 99.5 \%$ and $87.24 \%$ similarity. Thus, the geometric accuracy of the theoretical 3D modeled proteins was rectified to analyze the quality of proteins and the reliability of protein structures were validated by using SAVS. The structural statistical measures of modeled proteins were derived from X-ray crystallographic data.

Table 2- Quality parameters of homology modeled Wnt proteins (3D structure)

\begin{tabular}{|lccc|} 
Parameters & $\boldsymbol{\beta}$-catenin & APC & GSK-3 $\beta$ \\
\hline Poor Rotamers & $0.00 \%$ & $0.00 \%$ & $0.00 \%$ \\
Procheck & $92.68 \%$ & $94.80 \%$ & $89.80 \%$ \\
Overall Quality factor & 93.922 & 98.817 & 87.278 \\
RMSD & 0.0136 & 0.39 & 0.22 \\
Q-score & 0.682 & 0.662 & 0.934 \\
Average Z-score & -1.028 & -1.273 & -1.858 \\
SDM & $8.90 \%$ & $6.80 \%$ & $16.00 \%$ \\
Template & 2Z6GA & 1th1c & 3PxrA \\
\hline
\end{tabular}

The resultant protein structures were used to predict the active site amino acids and to calculate the electrostatic and Van-der-Waals interactions between residues of complex proteins. The active site amino acids were predicted based on RMSD values [Table-2] and the resulting amino acids further used as active site amino acids. The sequence similarity was calculated using ClustalX. Yet rotamer analysis, ramachandran outliers and quality factor was measured by Molprobity server and SAVS server. Chimera 1.5.7 was used for $\mathrm{Q}$-score, SDM and RMSD values.

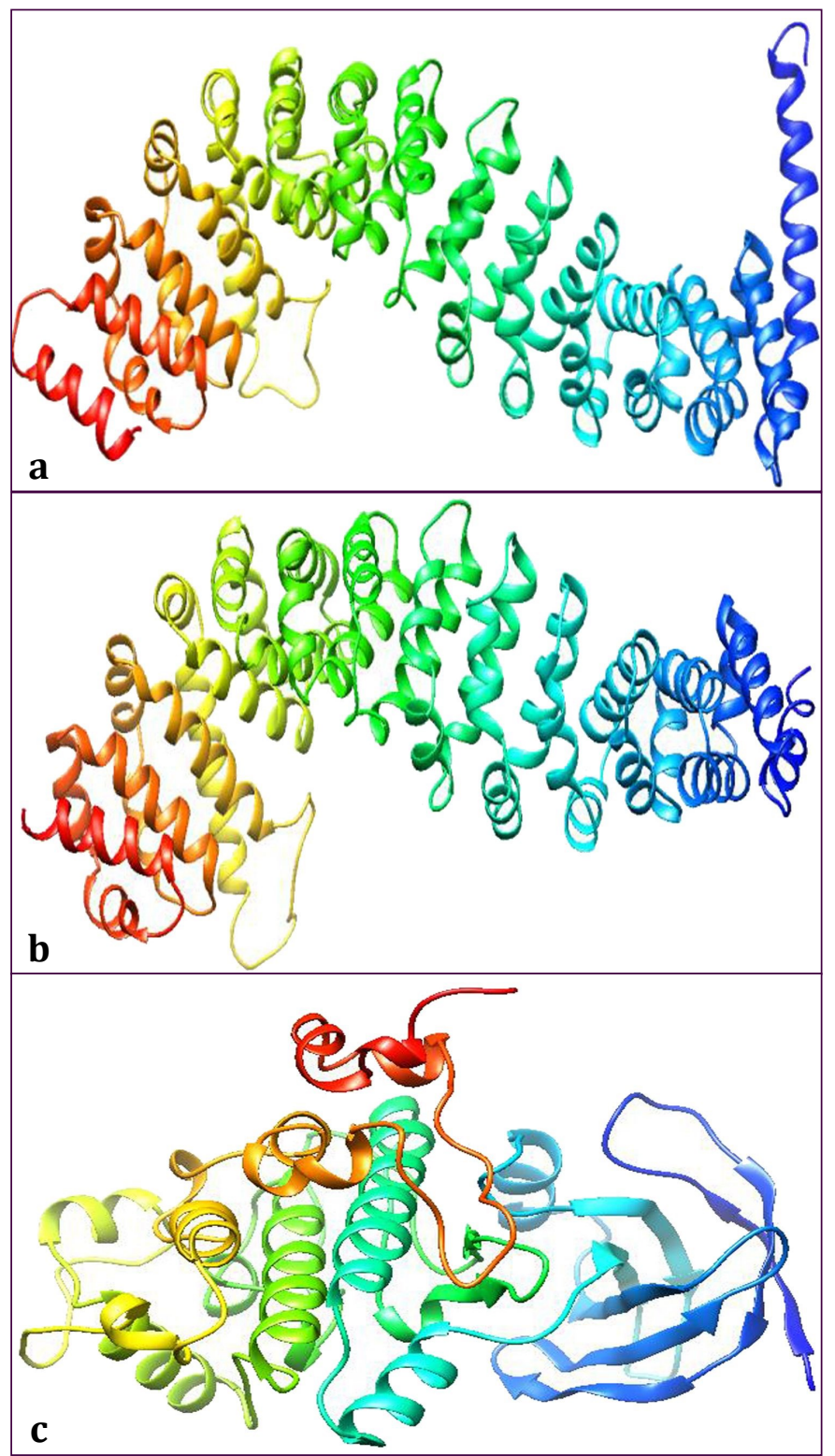

Fig. 1- The 3D modeled structure of Wnt Signaling proteins. (a) $\beta$ catenin and 2Z6GA; (b) APC and 1th1c template; (c) GSK-3 $\beta$ and 3PxrA.

\section{Ligand Selection and Molecular Docking}

The ligand molecules were retrieved from Pubchem compound database and these compounds were introduced to pharmacophore analysis that analyzed by Hyperchem 7.5 Professional [Table-3] based on biological properties. The prevailed ligand molecules has done by molecular docking and the active site receptor proteins were performed using AutoDock program. This has been shown to reproduce experimentally observed binding modes in terms of lowest docking energy successfully. The best possible binding modes of ligand molecules at three target protein active sites were displayed in [Fig-2](a), (b) \& (c). 
Table 3- Properties of Bm derivatives based on data obtained from drug bank

\begin{tabular}{|lclcc|} 
Compound Name & $\begin{array}{c}\text { Pubchem } \\
\text { ID }\end{array}$ & $\begin{array}{c}\text { Molecular } \\
\text { Formula }\end{array}$ & $\begin{array}{c}\text { Mass } \\
\text { (g/mol) }\end{array}$ & Log P \\
\hline Butrin & 164630 & $\mathrm{C}_{27} \mathrm{H}_{32} \mathrm{O}_{15}$ & 596.53398 & -1.8 \\
Isobutrin & 5281256 & $\mathrm{C}_{27} \mathrm{H}_{32} \mathrm{O}_{15}$ & 596.53398 & -0.8 \\
Butein & 5281222 & $\mathrm{C}_{15} \mathrm{H}_{12} \mathrm{O}_{5}$ & 272.25278 & 2.8 \\
Butin & 92775 & $\mathrm{C}_{15} \mathrm{H}_{12} \mathrm{O}_{5}$ & 272.25278 & 1.8 \\
Coreopsin & 25245366 & $\mathrm{C}_{21} \mathrm{H}_{22} \mathrm{O}_{10}$ & 434.39338 & 1 \\
Isocoreopsin & 193124 & $\mathrm{C}_{21} \mathrm{H}_{22} \mathrm{O}_{10}$ & 434.39338 & 0 \\
Monospermoside & 42607524 & $\mathrm{C}_{21} \mathrm{H}_{22} \mathrm{O}_{10}$ & 434.39338 & 1 \\
Isomonospermoside & 42607822 & $\mathrm{C}_{21} \mathrm{H}_{22} \mathrm{O}_{10}$ & 434.39338 & 0 \\
\hline
\end{tabular}

In this study, we have identified the phosphorylated sites of both upstream and downstream pathways of Wnt signaling proteins, $\beta$ catenin, APC and GSK-3 $\beta$, and their impact on CRC. These findings implied the series of event such as loss of phosphorylation in GSK-3 $\beta$ at the position of $9(S-A) A A$, prevention of phosphorylation in phosphate primed glycogen synthase at $96(\mathrm{R}-\mathrm{A}) \mathrm{AA}$, reduced activity towards AXIN 1 at $128(\mathrm{~L}-\mathrm{A}) \mathrm{AA}$, the sequence conflicts in the region of $28(\mathrm{~V}-\mathrm{G}) \mathrm{AA}$ and $356(\mathrm{~L}-\mathrm{H}) \mathrm{AA}$ [38]. The GSK $-3 \beta$ strongly interacts with phytochemicals of $B m$ floral extracts; the interaction energy and binding amino acids were listed in [Table-4]. In mutational sites, the amino acid Ser9, Arg96, Lys128, Val28 and Lys356 was interacted with butrin and isobutrin showed good interaction with inhibitory binding residues. Other residues includes Ser66, Asp133, Tyr134, Ile62, Asp200, Ser203, Ala20, Ala21, Ala39, GIn28, Leu31, Thr42 and Ala43 exhibited strong interaction with ligand molecules by forming 5 and 4 hydrogen bond linkages. However, the binding energy of butrin $(-9.04 \mathrm{Kcal} / \mathrm{mol})$ and Isobutrin $(-8.24 \mathrm{Kcal} / \mathrm{mol})$ were showed in [Fig-3](a) \& (b).

The putative APC phosphorylation sites SER-1385, THR-1388, SER-1389, SER-1391, SER-1501, SER-1504, SER-1505, SER1507 and SER-1510 were converted to alanine from GST-APC, make S-A mutants [39]. In APC protein, the butrin and isobutrin were strongly bound with the active sites of SER1503, TRP338, THR339, ALA295, ASN290, LYS335, LEU1511, LYS1518, and ARG1523 residues, based on 4 and 7 hydrogen bonds respectively. Besides, the binding energy of butrin $(-7.38 \mathrm{Kcal} / \mathrm{mol})$ and isobutrin $(-10.88 \mathrm{kcal} / \mathrm{mol})$ were shown in [Fig-3](c) \& (d). However, the other ligand molecules reported to have a weak interaction with APC active site amino acids [Table-5].

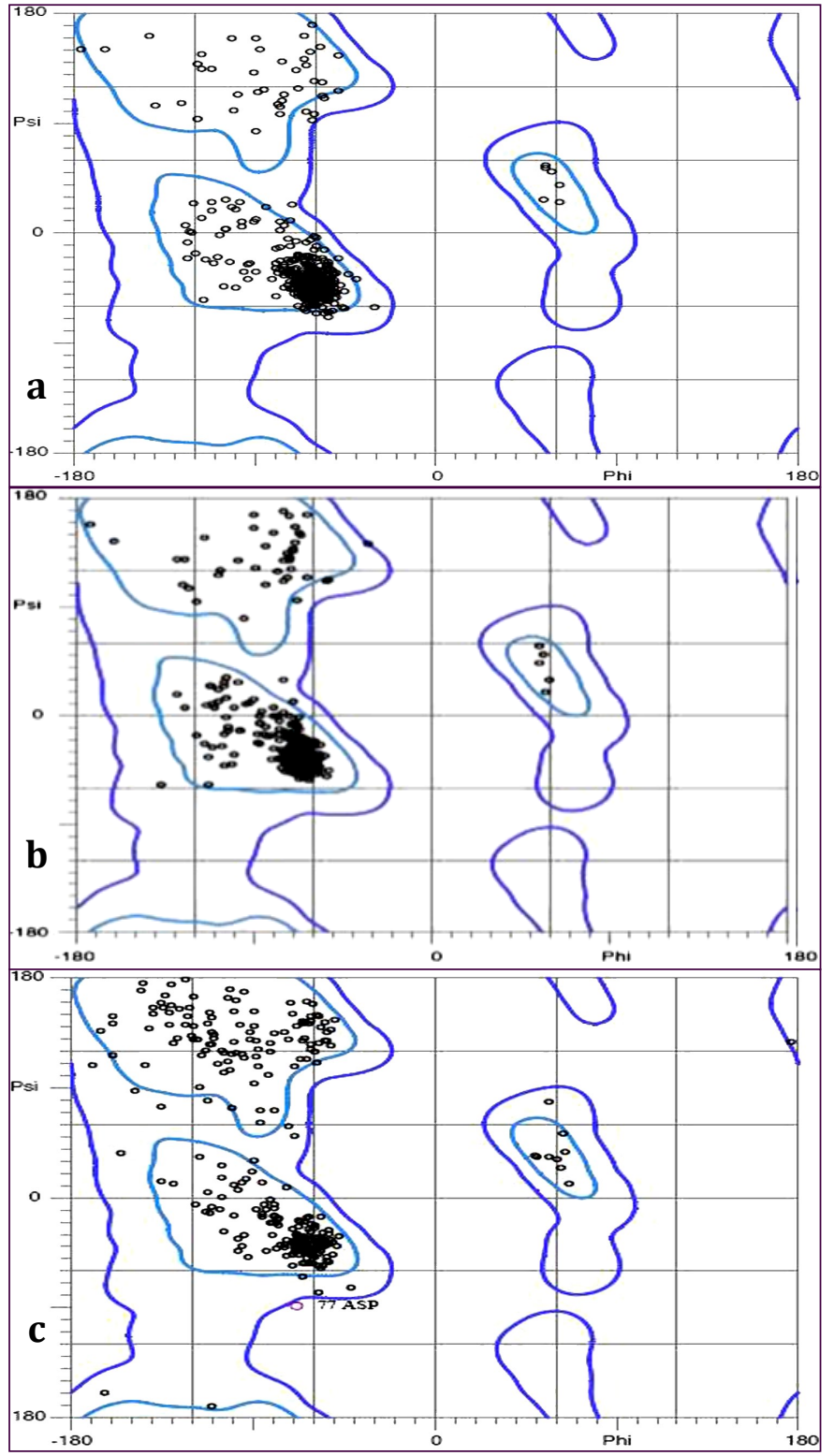

Fig. 2- Structural statistical measure of Wnt signaling proteins by using Ramachandran plot (a) $\beta$-catenin showed $97.48 \%$ ERRAT, 93.92\% Quality factor, outlier 0.03\%; (b) APC domain showed 94.8\% ERRAT, Quality factor showed 98.817; (c) GSK-3ß showed 89.80\% ERRAT, $87.278 \%$ Quality factor

Table 4- Docking results of GSK-3 $\beta$ protein binds with BM extracted Phytochemicals

\begin{tabular}{|c|c|c|c|}
\hline Compounds & H-bonds & Binding Energy (Kcal/mol) & Binding Amino Acids \\
\hline Butrin & 5 & -9.04 & Ser66, Asp133, Tyr134, Ile62, Asp200, Ser203 \\
\hline Isobutrin & 4 & -8.24 & Ala20, Ala21, Ala39, Gln28, Leu31, Thr42, Ala43 \\
\hline Butein & 3 & -7.36 & Ala39, Gly38, Thr42, Leu31, lle35 \\
\hline Butin & 2 & -6.91 & Ala39, Thr40, Thr42, Ala43 \\
\hline Coreopsin & 3 & -3.19 & Ala39, Thr42, Ala43 \\
\hline Isocoreopsin & 2 & -3.34 & Leu31, Asp32, Gly38, Ala39 \\
\hline Monospermoside & 2 & -2.1 & $\mathrm{G} \ln 27, \mathrm{G} \ln 28$ \\
\hline Isomonospermoside & 3 & -4.02 & His36, Gly38, Thr42 \\
\hline
\end{tabular}


Navaneethakrishnan P., Prashantha C.N., Boopathi S., Sabitha R. and Mathan G.

Table 5- Docking results of APC protein binds with BM extracted Phytochemicals

\begin{tabular}{|lccc|}
\hline Compounds & H-bonds & Binding Energy (Kcal/mol) & Binding Amino Acids \\
\hline Butrin & 4 & -7.38 & Ser1503, Trp338, Thr339, Ala295 \\
Isobutrin & 7 & -10.88 & Asn290, Lys335, Leu1511, Lys1518, Arg1523 \\
Butein & 3 & -8.05 & His219, Arg1523, Gln1517, Glu1513, lle1516, Leu1511, Pro1514, Phe1515, lle1516 \\
Butin & 3 & -5.82 & Arg612, Glu571 \\
Coreopsin & 3 & -4.17 & His223, lle1516, Pro1526, lle1522 \\
Isocoreopsin & 2 & -4.50 & Gln1517, Ile1516 \\
Monospermoside & 2 & -3.18 & Ala1485, Asp1484 \\
Isomonospermoside & 1 & -2.49 & Ile1516, Gln1517 \\
\hline
\end{tabular}

In $\beta$-catenin the phosphorylated amino acids Ser23, Ser29, Ser33, Ser37, Thr41 and Ser45 was located at GSK-3ß [40].The other amino acids includes Phe253, His260, Lys292, Lys312, Lys345, Trp383, Asn426, Lys435, Arg469, His470, Lys508 and Phe654 present in armadillo repeats recorded strong interaction with butrin and isobutrin ligand molecules. The interaction energy of butrin and isobutrin was $-8.08 \mathrm{Kcal} / \mathrm{mol}$ and $-6.71 \mathrm{kcal} / \mathrm{mol}$ that formed 4 and 8 hydrogen bonds respectively [Fig-3](e) \& (f). The clustering of docking results was predicted in [Table-6].

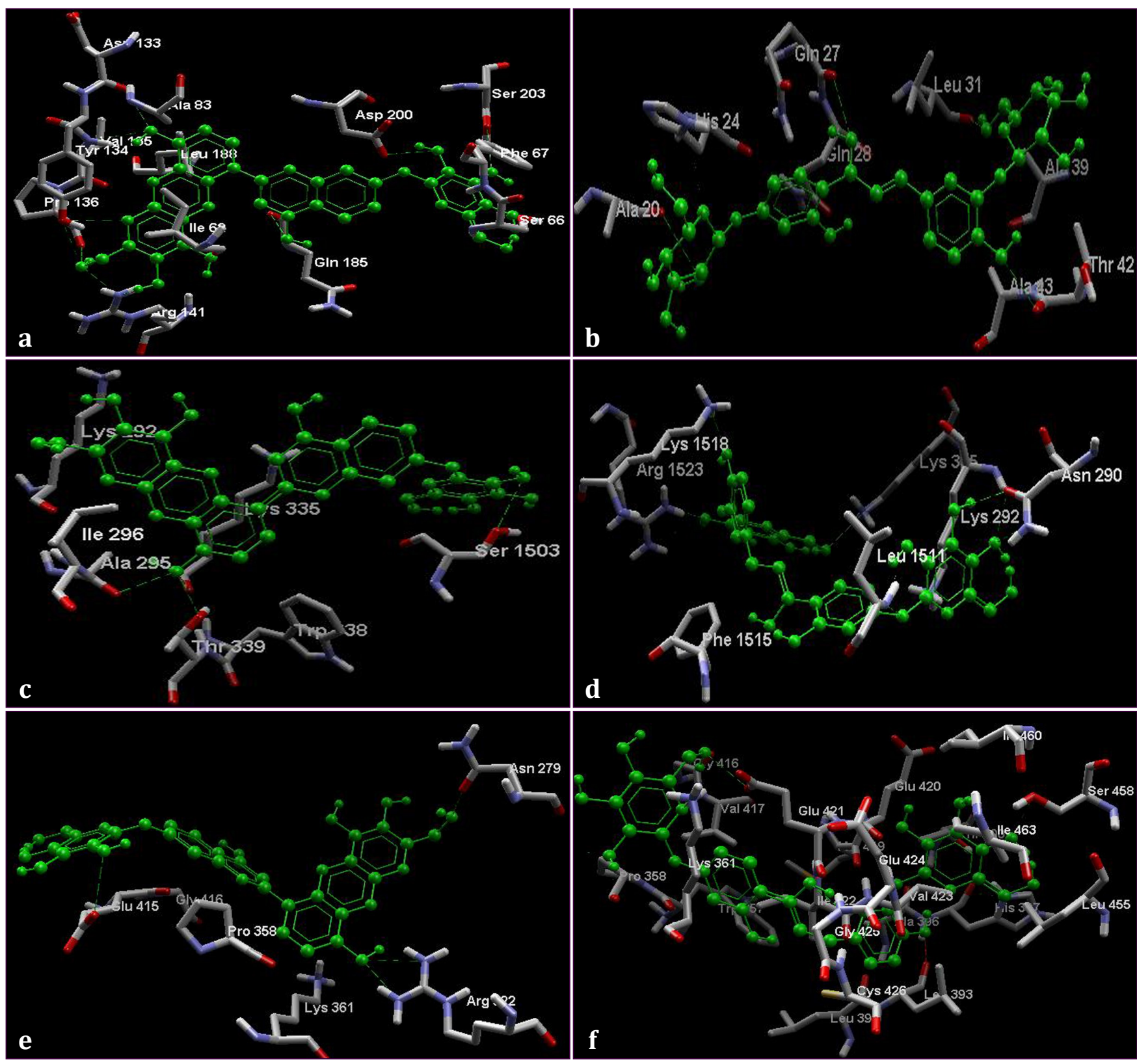

Fig. 3- Docking results of Wnt signaling proteins (green dotes denoted strong hydrogen bonds); Interaction of GSK-3ß with butrin (a) and isobutrin (b); Interaction of APC with butrin (c) and isobutrin (d); Interaction of $\beta$-catenin with butrin (e) and isobutrin (f). 
Table 6- Docking results of $\beta$-catenin protein binds with BM extracted Phytochemicals

\begin{tabular}{|lccc|}
\hline Compounds & H-bonds & Binding Energy (Kcal/mol) & Binding Amino Acids \\
\hline Butrin & 4 & -8.08 & Asn279, Arg322, Glu415 \\
Isobutrin & 8 & -6.71 & Ala395, Arg418, Glu424, Gly425, Trp357, Val364 \\
Butein & 3 & -4.38 & Arg322, Asn279, Cys319, Glu315, Glu415, His323, \\
Butin & 3 & -3.60 & Glu420, Glu421, Gly425, \\
Coreopsin & 3 & -2.11 & Arg368, Arg418, Arg465, Glu421, Thr507 \\
Isocoreopsin & 3 & -2.08 & Gln411, Phe413, Glu421, Lys361 \\
Monospermoside & 2 & -1.55 & Arg322, Lys361, Gly416, Glu415 \\
Isomonospermoside & 3 & -2.65 & Arg322, Ser278, Asn279, Pro316, Glu315 \\
\hline
\end{tabular}

The interaction between flavonoids and membrane was constructed by formation of hydrogen bond between charged lipid head group and uncharged flavonoids through entry of hydrophilicity [41]. The interaction depends on chemical structure of flavonoids and its partition of hydrophobic reaction by micellar structure in the membrane layer. As a result, the hydrogen bond interaction aided to stabilize the complex of ligand molecules and target site protein.Though there were several Wnt target chemotherapeutic compounds for CRC treatment such as indomethacin [42-44], Sulindac [45], Aspirin [46], Glive compound [47] and Endostatin [48]. Our insilico model investigation strongly revealed that the compounds of butrin and isobutrin were potentially inhibited Wnt related downstream targeted proteins of CRC.

\section{Conclusion}

Altogether our investigation concluded that the ligands from $\mathrm{Bm}$ derivatives such as butrin and isobutrin were docked well with targets of GSK3 $\beta, A P C$ and $\beta$-catenin proteins related to CRC. Ultimately, this result strongly hints that the butrin and isobutrin would be considered as potent inhibitor against Wnt/ $\beta$-Catenin associated cancers. Moreover, this study takes a stairs to undergo further subtype specific drug toxicity against CRC by using in vitro and in vivo models.

\section{Acknowledgement}

The support for this study greatly granted by Department of Science and Technology-Science and Engineering Research Board (DSTSERB) (Grant No: SR/FT/LS-122/2009 Dt.07.12.2011), New Delhi. Navaneethakrishnan P. and Boopathi S. are the Research and Project Fellows in DST-PURSE and DST-SERB, New Delhi.

\section{Conflicts of Interest: None declared.}

\section{References}

[1] Polakis P. (2000) Genes Dev., 14, 1837-1851.

[2] Chen J., Huang X.F. (2009) Cancer Biology \& Therapy, 8(14), 1313-1317.

[3] Qiang D., David A.G. (2010) Immunopathol Dis. Therapy, 1(3), 155-181.

[4] He T.C., Sparks A.B., Rago C., Hermeking H., Zawel L., da Costa L.T., Morin P.J., Vogelstein B., Kinzler K.W. (1998) Science, 281, 1509-1512.

[5] He T.C., Chan T.A., Vogelstein B., Kinzler K.W. (1999) Cell, 99, 335-345.

[6] Tetsu O., McCormick F. (1999) Nature, 398, 422-426.

[7] Mann B., Gelos M., Siedow A., Hanski M.L., Gratchev A., llyas M., Bodmer W.F., Moyer M.P., Riecken E.O., Buhr H.J., Hanski C. (1999) Proc. Natl. Acad. Sci., 96, 1603-1608.
[8] Crawford H.C., Fingleton B.M., Rudolph-Owen L.A., Goss K.J., Rubinfeld B., Polakis P., Matrisian L.M. (1999) Oncogene, 18, 2883-2889.

[9] Xu L., Corcoran R.B., Welsh J.W., Pennica D., Levine A.J., (2000) Genes Dev., 14, 585-595.

[10]Kim L., Kimmel A.R. (2000) Curr. Opin. Genet. Dev., 10, 508514.

[11]Hoeflich K.P., Luo J., Rubie E.A., Tsao M.S., Jin O., Woodgett J.R. (2000) Nature, 406, 86-90.

[12]Rayasam G.V. (2009) Br. J. Pharmacol., 156(6), 885-898.

[13]Ougolkov A.V., Billadeau D.D. (2006) Future Onco., 2, 91-100.

[14]Breitman M., Zilberberg A., Caspi M., Rosin-Arbesfeld R., (2008) Biochim. Biophys. Acta., 1783, 1792-1802.

[15]Behrens J., von Kries J.P., Kühl M., Bruhn L., Wedlich D., Grosschedl R., Birchmeier W. (1996) Nature, 382, 638-642.

[16]Cadigan K.M., Nusse R. (1997) Genes Dev., 11(24), 3286-305.

[17]Miller J.R., Moon R.T. (1996) Genes Dev., 10(20), 2527-2539.

[18]Miyaki M., Konishi M., Kikuchi-Yanoshita R., Enomoto M., Igari T., Tanaka K., Muraoka M., Takahashi H., Amada Y., Fukayama M. (1994) Cancer Res., 54, 3011-3020.

[19]Polakis P. (1995) Curr. Opin. Genet. Dev., 5, 66-71.

[20]Rubinfeld B., Souza B., Albert I., Müller O., Chamberlain S.H., Masiarz F.R., Munemitsu S., Polakis P. (1993) Science, 262, 1731-1734.

[21]Geeta R., Prakash R., Navgeet S., Neeru V., Sumit J. (2011) International Research Journal of Pharmacy, 2, 98-108.

[22]Zafar R., Nahid A., Abubakar K., Khursheed A., Tariq M.H. (2010) The Journal of Pharmacology and Experimental Therapeutics, 333, 354-363.

[23]Wagner H., Geyer B., Fiebig M., Kiso Y., Hikino H. (1986) Planta Med., 52, 77-79.

[24]Gupta S.R., Ravindranath B., Seshadri T.R. (1970) Phytochemistry, 9, 2231-2235.

[25]Tenzin C., Surendra K.S., Vijay Kumar (2010) Journal of Ethnopharmacology, 129, 208-213.

[26]Altschul S.F., Gish W., Miller W., Myers E.W., Lipman D.J., (1990) J. Mol. Biol., 215, 403-410.

[27]Altschul S.F., Madden T.L., Schaffer A.A., Zhang J., Zhang Z., Miller W., Lipman D.J. (1997) Nucleic Acids Res., 25, 33893402.

[28]Thompson J.D. (2002) Curr. Protoc. Bioinformatics., DOI: 10.1002/0471250953.bi0203s00.

[29]Deshpande N., Addess K.J., Bluhm W.F., Merino-Ott J.C., 
Townsend-Merino W. (2005) Nucleic Acids Res., 33, 233-237.

[30]Laskowski R.A., MacArthur M.W., Moss D.S., Thornton J.M., (1993) J. Appl. Cryst., 26, 283-291.

[31]Gopalakrishnan K., Sowmiya G., Sheik S.S., Sekar K. (2007) Protein Pept Lett., 14, 669-671.

[32]Emsley P., Cowtan K. (2004) Acta Crystallogr., 60, 2126-2132.

[33]Krissinel E., Henrick K. (2004) Acta Crystallogr., 60, 2256-2268.

[34]Laurie A.T., Jackson R.M. (2005) Bioinformatics, 21,1908-1916.

[35]Baker D., Sali A. (2001) Science, 294, 93-96.

[36]Edwards B.S., Bologa C., Young S.M., Balakin K.V., Prossnitz E.R., Savchuck N.P., Sklar L.A., Oprea T.I. (2005) Mol. Pharmacol., 68, 1301-1310.

[37]Guner O., Clement O., Kurogi Y. (2004) Curr. Med. Chem., 11, 2991-3005.

[38]Kim E.A., Kim J.E., Sung K.S., Choi D.W., Lee B.J., Choi C.Y. (2010) Biochem. Biophys. Res. Commun., 394(4), 966-971.

[39]Yang J., Zhang W., Evans P.M., Chen X., He X., Liu C., (2006) J. Biol. Chem., 281(26), 17751-17757.

[40]Miyaki M., lijima T., Kimura J. (1999) Cancer Res., 59, 45064509.

[41]Hendrich A.B. (2006) Acta Pharmacologica Sinica., 27(1), 2740.

[42]Dihlmann S., Siermann A., von Knebel Doeberitz M. (2001) Oncogene, 20, 645-653.

[43]Smith M.L., Hawcroft G., Hull M.A. (2000) Eur. J. Cancer, 36, 664-674.

[44]Hawcroft G., D'Amico M., Albanese C., Markham A.F., Pestell R.G., Hull M.A. (2002) Carcinogenesis, 23, 107-114.

[45]Boon E.M., Keller J.J., Wormhoudt T.A., Giardiello F.M., Offerhaus G.J., van der Neut R., Pals S.T. (2004) Br. J. Cancer, 90, 224-229.

[46]Germann A., Dihlmann S., Hergenhahn M., von Knebel Doeberitz M., Koesters R. (2003) Int. J. Cancer, 106, 187-197.

[47]Zhou L., An N., Haydon R.C., Zhou Q., Cheng H., Peng Y., Jiang W., Luu H.H., Vanichakarn P., Szatkowski J.P., Park J.Y., Breyer B. (2003) Cancer Lett., 193, 161-170.

[48]Hanai J., Gloy J., Karumanchi S.A., Kale S., Tang J., Hu G., Chan B., Ramchandran R., Jha V., Sukhatme V.P., Sokol S., (2002) J. Cell Biol., 158, 529-539. 